\title{
Hyaluronic Acid-Glycine-Cholesterol Conjugate-Based Nanoemulsion as a Potent Vaccine Adjuvant for T Cell-Mediated Immunity
}

\author{
Chih-An Lin ${ }^{1}{ }^{(D}$, Hui-Min Ho ${ }^{2}$, Parthiban Venkatesan ${ }^{3}{ }^{D}$, Chiung-Yi Huang ${ }^{2}$, Yu-Jhen Cheng ${ }^{2}$, Yu-Hsing Lin ${ }^{4}$, \\ Hua-Yang Lin ${ }^{4}$, Tzu-Yang Chen ${ }^{3}\left(\mathrm{D}\right.$, Ming-Hsi Huang ${ }^{1,2, *(D)}$ and Ping-Shan Lai ${ }^{1,3, *}$
}

check for updates

Citation: Lin, C.-A.; Ho, H.-M.; Venkatesan, P.; Huang, C.-Y.; Cheng, Y.-J.; Lin, Y.-H.; Lin, H.-Y.; Chen, T.-Y.; Huang, M.-H.; Lai, P.-S. Hyaluronic Acid-Glycine-Cholesterol Conjugate-Based Nanoemulsion as a Potent Vaccine Adjuvant for T Cell-Mediated Immunity. Pharmaceutics 2021, 13, 1569. https://doi.org/10.3390/ pharmaceutics13101569

Academic Editors: Yogita Patil-Sen and Mohamed Elsawy

Received: 5 August 2021

Accepted: 18 September 2021

Published: 27 September 2021

Publisher's Note: MDPI stays neutral with regard to jurisdictional claims in published maps and institutional affiliations.

Copyright: (c) 2021 by the authors. Licensee MDPI, Basel, Switzerland. This article is an open access article distributed under the terms and conditions of the Creative Commons Attribution (CC BY) license (https:/ / creativecommons.org/licenses/by/ $4.0 /)$.
1 Ph.D. Program in Tissue Engineering and Regenerative Medicine, National Chung Hsing University, Taichung City 402204, Taiwan; fire0082@gmail.com

2 National Institute of Infectious Diseases and Vaccinology, National Health Research Institutes, Miaoli City 350401, Taiwan; jasminho@nhri.edu.tw (H.-M.H.); anita9132@nhri.edu.tw (C.-Y.H.); yujhen@nhri.edu.tw (Y.-J.C.)

3 Department of Chemistry, National Chung Hsing University, Taichung City 402204, Taiwan; venkatesanwala@gmail.com (P.V.); cypanjimmy@gmail.com (T.-Y.C.)

4 Preclinical Development Research Department, Holy Stone Healthcare Co., Ltd., Hsinchu 114066, Taiwan; starlin@hshc.com.tw (Y.-H.L.); louislin@hshc.com.tw (H.-Y.L.)

* Correspondence: huangminghsi@nhri.org.tw (M.-H.H.); pslai@email.nchu.edu.tw (P.-S.L.); Tel.: +886-37-206166 (ext. 37742) (M.-H.H.); +886-4-22840411 (ext. 428) (P.-S.L.)

Abstract: Clinical cases of allergic reaction that are due to excipients containing polyethylene glycol (PEG), a hydrophilic molecule commonly used in drug/vaccine formulations, has attracted much attention in recent years. In order to develop PEG-free adjuvants, we investigated the feasibility of natural ingredients in the human body such as hyaluronic acid in the form of hyaluronic acid-glycine cholesterol (HACH) conjugate as an excipient for vaccine formulation. Interestingly, HACH grafted with $\sim 13$ wt. $\%$ cholesterol has good water dispersity and can serve as an emulsifier to stabilize the squalene/water interfaces, yielding a milky white and isotropic emulsion (SQ@HACH) after being passed through a high-shear microfluidizer. Our results show that SQ@HACH particles possessed a unimodal average hydrodynamic diameter of approximately $190 \mathrm{~nm}$ measured by dynamic light scattering and exhibited good stability upon storage at $4{ }^{\circ} \mathrm{C}$ and $37{ }^{\circ} \mathrm{C}$ for over 20 weeks. The results of immunogenicity using a mouse model with ovalbumin (OVA) as the antigen revealed that SQ@HACH significantly enhanced antigen-specific immune responses, including the polarization of IgG antibodies, the cytokine secretions of T cells, and enhancement of cytotoxic T lymphocyte (CTL) activation. Moreover, SQ@HACH revealed lower local inflammation and rapidly absorbing properties compared with $\mathrm{AlPO}_{4}$ after intramuscular injection in vivo, indicating the potential functions of the HA-derived conjugate as an excipient in vaccine formulations for enhancement of T cell-mediated immunity.

Keywords: hyaluronic acid; cholesterol; squalene; nanoemulsion; vaccine adjuvants; PEG-free formulation; allergy

\section{Introduction}

Vaccination is the most effective strategy to prevent or limit the severity of infectionassociated syndromes by training the immune system to recognize and destroy the invading pathogens [1]. For safety issues, new-generation vaccine candidates usually employ a highly purified sub-portion of the pathogen as an antigen; however, these components often lack immunogenicity, thus necessitating adjuvants to facilitate the induction of adaptive immunity [2]. Currently, the most common salts for large-scale vaccination are aluminum-based mineral salts that mainly function as a depot to drive humoral immunity; however, they are usually limited by the weak stimulation of cell-mediated immunity $[3,4]$. 
Thus, it is important to make an inventory of suitable compounds for the development of an efficient adjuvant [5,6] with an acceptable profile of reactogenicity [7].

Several developmental adjuvants have been approved or authorized in prophylactic human vaccines for enhanced cell-mediated immunity, examples include squalene emulsions, saponins, Toll-like receptor (TLR) agonists, liposomes, and lipid nanoparticles [3]. While allergic reactions to vaccines are extremely rare clinically [8], excipients containing polyethylene glycol (PEG) are speculatively implicated in some severe cases such as anaphylaxis [9-11]. Currently, nanomaterial-based vaccines contain PEG-derivatives as a vaccine adjuvant (MF59 and AS03) and an excipient in COVID-19 vaccines, including licensed BNT162b2 and those under EUA (ChAdOx1 nCoV-19 and mRNA-1273) [12,13]. The presumption of PEG-induced allergic reaction was supported by the finding of complement activation-related pseudoallergy (CARPA) triggered by pre-existing anti-PEG IgG or IgE-mediated hypersensitivity reactions [14-16]. The Centers for Disease Control and Prevention has recommended the administration of the Pfizer/BioNTech and Moderna COVID-19 vaccines, and exclusion of any person who has a history of allergic reaction associated with any of the vaccine components, including PEG and PEG derivatives, such as excipient polysorbates as the stabilizer or emulsion adjuvant [14]. Therefore, it is necessary to develop a PEG-free adjuvant considering the potential risks of PEG allergy.

Hyaluronic acid (HA) is a water-soluble glycosaminoglycan consisting of repeating disaccharide units of $\mathrm{N}$-acetyl glucosamine and glucuronic acid, it is naturally present in the human body [17]. HA has been widely used in biomedical applications, such as in joint cavity injections for the treatment of arthritis and in dermal fillers for aesthetic medicine because of its controlled biodegradability, biocompatibility in vivo, and ease of modification [17-19]. Although some clinical case studies have described HA as a dermal filler that may cause a foreign body reaction in the injection site with local inflammation and late granuloma formation [20,21], HA is still classified as a biomaterial of low immunogenicity and allergenicity [22,23]. The administration of high purity or non-animal source HA does not elicit cellular or humoral immunity, including anti-HA IgE and IgG production based on clinical or laboratory evidences [23,24]. HA has shown poor interaction with blood components, but not shown any sensory-motor or behavioral changes after epidural administration in rabbits; furthermore, HA does not produce genetic damage in Ames Salmonella assay [25]. These features reveal that HA possesses low cytotoxicity, neurotoxicity, and mutagenicity. Some studies showed that HA might inhibit the proliferation of several cells based on the molecular weight and dosage of HA [26-29]. Generally, high concentration of high molecular weight HA may inhibit the production of pro-inflammatory mediators [30] and remove inflammatory cells by inhibition of proliferation to reverse the effects of HA fragments [27]. Interestingly, low molecular weight HA or HA fragments have an opposite impact, inducing cell proliferation [26,31], promoting the production of inflammatory mediators [30], and successfully enhancing the activation of dendritic cells and T cells [32]. They can thus act as a potential biomaterial for the development of adjuvants based on their safety and immune-related regulatory functions [33,34]. Therefore, it is important to verify the relationship between molecular weight and immune activation of HA-based materials.

In this study, we designed a squalene-based nanoemulsion using a PEG-free emulsifier composed of natural HA, glycine, and cholesterol and then investigated the potential of HA-glycine-cholesterol (HACH) conjugates for the development of a vaccine adjuvant. The biocompatibility and possible immune regulation, including $\mathrm{T}$ cell and $\mathrm{B}$ cell responses to squalene-based $\mathrm{HACH}$ nanoemulsion mixed with ovalbumin (OVA) antigen protein after single-dose intramuscular injection in mice were evaluated in vivo and ex vivo.

\section{Materials and Methods}

\subsection{Materials}

The $100 \mathrm{kDa}$ hyaluronic acid (HA) was provided by Holy Stone Healthcare (Taipei, Taiwan). Cholesterol was purchased from Alfa Aesar (Tewksbury, MA, USA). n-(tert- 
Butoxycarbonyl) glycine (Boc-Gly-OH), ethyl cyanohydroxyiminoacetate (Oxyma), diisopropylcarbodiimide (DIC) and phosphotungstic acid (PTA) were purchased from SigmaAldrich (Burlington, MI, USA). Dicyclohexylcarbodiimide (DCC) and 4-dimethylaminopyridine (DMAP) were purchased from ACROS (Geel, Belgium). Dichloromethane (DCM) was purchased from Seedchem (Melbourne, Australia). Dimethyl sulfoxide (DMSO) was purchased from UniRegion Bio Tech (New Taipei, Taiwan). Trifluoroacetic acid (TFA) was purchased from Lancaster (Lancaster, Lancashire, UK).

\subsection{Synthesis and Characterization of Hyaluronic Acid-Gly-Cholesterol (HACH) Conjugates \\ 2.2.1. Synthesis of Boc-Gly-Cholesterol}

An amount of $1000 \mathrm{mg}$ ( $2.59 \mathrm{mmol})$ of cholesterol and $480 \mathrm{mg}(2.74 \mathrm{mmol})$ of Boc-Gly$\mathrm{OH}$ were dissolved in $125 \mathrm{~mL}$ of DCM, and then $1070 \mathrm{mg}(5.18 \mathrm{mmol}$ ) of DCC and $372 \mathrm{mg}$ ( $3.04 \mathrm{mmol}$ ) of DMAP were added into the mixture solution and reacted for $12 \mathrm{~h}$ under a $\mathrm{N}_{2}$ atmosphere at room temperature. The reaction was traced by thin layer chromatography (TLC) to confirm that the coupling reaction had completed. After removing the solvent by rotary evaporation, the residues were purified by silica gel chromatography with a mobile phase mixture of hexane/acetone at $3 / 1$. The structure of the product was identified by ${ }^{1} \mathrm{H}-\mathrm{NMR}$ spectroscopy (Agilent Technologies $400 \mathrm{MHz}$ NMR, Santa Clara, CA, USA) and mass spectroscopy (TSQ Altis ${ }^{\mathrm{TM}}$ Triple Quadrupole Mass Spectrometer, Thermo Fisher Scientific, Waltham, MA, USA). ${ }^{1} \mathrm{H}-\mathrm{NMR}\left(400 \mathrm{MHz}, \mathrm{CDCl}_{3}\right) \delta 5.37(\mathrm{~d}, J=4.4 \mathrm{~Hz}, 1 \mathrm{H}), 4.99$ $(\mathrm{s}, 1 \mathrm{H}), 4.68(\mathrm{~m}, 1 \mathrm{H}), 3.87(\mathrm{~d}, J=5.3 \mathrm{~Hz}, 2 \mathrm{H}), 2.33(\mathrm{~d}, J=7.8 \mathrm{~Hz}, 2 \mathrm{H}), 2.01(\mathrm{~m}, 2 \mathrm{H}), 1.95$ $(\mathrm{t}, J=4.5 \mathrm{~Hz}, 1 \mathrm{H}), 1.90-1.77(\mathrm{~m}, 3 \mathrm{H}), 1.63-1.41(\mathrm{~m}, 9 \mathrm{H}), 1.45(\mathrm{~s}, 9 \mathrm{H}), 1.40-1.23(\mathrm{~m}, 5 \mathrm{H})$, $1.20-1.03(\mathrm{~m}, 8 \mathrm{H}), 1.01(\mathrm{~s}, 3 \mathrm{H}), 0.91(\mathrm{~d}, J=6.6 \mathrm{~Hz}, 3 \mathrm{H}), 0.86(\mathrm{dd}, J=6.6,1.6 \mathrm{~Hz}, 6 \mathrm{H}), 0.67$ (s, 3H); ESI-MS: $\mathrm{C}_{34} \mathrm{H}_{58} \mathrm{NO}_{4}{ }^{+}[\mathrm{M}+\mathrm{H}]^{+} 543.9 \mathrm{~m} / \mathrm{z}$.

\subsubsection{Deprotection of Boc-Gly-Cholesterol}

An amount of $500 \mathrm{mg}(0.92 \mathrm{mmol})$ of Boc-Gly-cholesterol was dissolved in $2 \mathrm{~mL}$ of DCM in an ice bath, and then $2 \mathrm{~mL}$ of TFA was added into the solution and stirred for $3 \mathrm{~h}$ under a $\mathrm{N}_{2}$ atmosphere at room temperature. The reaction was traced by TLC to check the completion of de-protection of Boc group. After de-protection, the mixture was neutralized with saturated $\mathrm{NaHCO}_{3}$ aqueous solution and the precipitate was filtered out and dried in vacuum to obtain the $\mathrm{NH}_{2}$-Gly-cholesterol white powder. The structure of $\mathrm{NH}_{2}-\mathrm{Gly}-$ cholesterol was identified by ${ }^{1} \mathrm{H}-\mathrm{NMR}$ spectroscopy (Agilent Technologies $400 \mathrm{MHz}$ NMR) and mass spectroscopy (TSQ Altis ${ }^{\mathrm{TM}}$ Triple Quadrupole Mass Spectrometer). ${ }^{1} \mathrm{H}-\mathrm{NMR}$ $\left(400 \mathrm{MHz}, \mathrm{CDCl}_{3}\right) \delta 5.37$ (broad s, $\left.1 \mathrm{H}\right), 4.68(\mathrm{~m}, 1 \mathrm{H}), 3.79$ (broad s, $\left.2 \mathrm{H}\right), 2.33(\mathrm{~m}, 2 \mathrm{H}), 2.01$ $(\mathrm{m}, 2 \mathrm{H}), 1.95(\mathrm{t}, J=4.5 \mathrm{~Hz}, 1 \mathrm{H}), 1.90-1.77(\mathrm{~m}, 3 \mathrm{H}), 1.63-1.41(\mathrm{~m}, 7 \mathrm{H}), 1.40-1.23(\mathrm{~m}, 6 \mathrm{H})$, $1.20-1.03(\mathrm{~m}, 7 \mathrm{H}), 1.01(\mathrm{~s}, 3 \mathrm{H}), 0.91(\mathrm{~d}, J=6.5 \mathrm{~Hz}, 3 \mathrm{H}), 0.86(\mathrm{~d}, J=6.5 \mathrm{~Hz}, 6 \mathrm{H}), 0.67(\mathrm{~s}, 3 \mathrm{H})$; ESI-MS: $\mathrm{C}_{29} \mathrm{H}_{50} \mathrm{NO}_{2}{ }^{+}[\mathrm{M}+\mathrm{H}]^{+} 444.2 \mathrm{~m} / z$.

\subsubsection{Conjugation of $\mathrm{HA}$ and $\mathrm{NH}_{2}$-Gly-Cholesterol}

An amount of $500 \mathrm{mg}$ (1.25 mmol, 1.0 eq.) sample of HA (100 kDa) was first dissolved in a mixture of $70 \mathrm{~mL}$ of water and $90 \mathrm{~mL}$ of DMSO. A mixture containing $250 \mathrm{mg}$ $(1.11 \mathrm{mmol})$ of Oxyma and $113 \mathrm{mg}\left(0.25 \mathrm{mmol}, 0.2 \mathrm{eq}\right.$.) of $\mathrm{NH}_{2}$-Gly-Cholesterol was dissolved in $10 \mathrm{~mL}$ of DMSO and then the resulting solution was added into the HA solution. The mixed solution was slowly added by $405 \mu \mathrm{L}(2.58 \mathrm{mmol})$ of DIC and stirred for $24 \mathrm{~h}$. The obtained solution was transferred into a 3500-MWCO dialysis bag and purified by sequential dialysis against $\mathrm{DMSO} /$ water $(50 / 50, v / v), 0.3 \mathrm{M} \mathrm{NaCl}$ aqueous solution, and pure water. Finally, water was removed from the dialyzed product solution by freeze-drying to obtain $\mathrm{HACH} 20$. The different DS\% of $\mathrm{HACH}$ was synthesized by adding corresponding equivalents of $\mathrm{NH}_{2}$-Gly-Cholesterol; $\mathrm{HACH} 10$ and HACH30 means 0.1 or 0.3 equivalent of $\mathrm{NH}_{2}$-Gly-Cholesterol for the $\mathrm{HA}$ conjugation, respectively. The conjugation ratio of $\mathrm{HACH}$ was determined by elemental analysis (Elementar vario EL cube, Langenselbold, Hesse, Germany). 
The DS\% of HACH was analyzed by an elemental analyzer (EA) and calculated using the following Formula (1):

$$
\mathrm{DS} \%=\frac{R_{y}-R_{0}}{R_{100}-R_{0}} \times 100 \%
$$

where $R_{y}$ is the $\mathrm{C} / \mathrm{N}$ ratio of $\mathrm{HACH}$, and $R_{0}$ and $R_{100}$ represent the $\mathrm{C} / \mathrm{N}$ ratios of unmodified $\mathrm{HA}$ and theoretical completely modified $\mathrm{HACH}(100 \%)$, respectively.

\subsection{Preparation and Characterization of HACH-Stabilized Squalene Emulsion (SQ@HACH)}

An amount of $100 \mathrm{mg}$ of HACH20 was dissolved in $9.5 \mathrm{~mL}$ of sodium citrate solution $(\mathrm{pH}=6.5,10 \mathrm{mM})$, and then $500 \mu \mathrm{L}$ of squalene was added into the HACH solution. The resulting solution was pre-mixed in a test tube rotator at $500 \mathrm{rpm}$ for $1 \mathrm{~h}$ and then homogenized through a high-pressure microfluidizer operated at 20,000 psi (Nanolyzer N2, Gogene Corporation, Hsinchu County, Taiwan). To evaluate the particle size and stability of SQ@HACH, aliquots of the SQ@HACH emulsion were loaded in 1.5-mL Eppendorf tubes and stored separately at $4{ }^{\circ} \mathrm{C}$ and $37^{\circ} \mathrm{C}$. At predetermined time points, the appearance and particle sizes of the emulsion were recorded. The particle size and polydispersity index (PDI) of HACH20 and SQ@HACH in water solutions were measured by dynamic light scattering (DLS, Malvern Zetasizer Nano ZS90, Malvern, UK). The HACH20 and SQ@HACH were stained by PTA negative staining and their morphology was observed by transmission electron microscopy (TEM, JEOL JEM-1400 electron microscopy, Tokyo, Japan).

\subsection{Animals and Ethics Statement}

Female C57BL/6 mice, 6-12 weeks old, were obtained from the National Laboratory Animal Center (Taipei, Taiwan). All animals were housed at the Animal Center of National Health Research Institutes (NHRI) and maintained in accordance with the institutional animal care protocol. All of the animal studies were approved by the animal committee of the NHRI (NHRI-IACUC-107149).

\subsection{Immunization In Vivo and Tissue Sample Preparation}

\subsubsection{Immunization Schedule}

C57BL/ 6 mice (three mice per group) were immunized by intramuscular injection at the quadriceps $(50 \mu \mathrm{L}$ each leg) with a total of $50 \mu \mathrm{g}$ of OVA in sodium citrate solution $(\mathrm{pH}=6.5,10 \mathrm{mM})$ in the absence or presence of SQ@HACH (squalene content: $5 \mu \mathrm{L}$ ). An amount of $50 \mu \mathrm{g}$ OVA with the aluminum mineral salt adjuvant $\left(\mathrm{AlPO}_{4}\right.$, aluminum content: $30 \mu \mathrm{g}$, BRENNTAG, Vejle, Denmark) was used as control adjuvant. These samples were gently homogenized by rotation prior to injection.

\subsubsection{Preparation of Muscular Tissues at the Injection Sites and Splenocyte Samples}

Fourteen days post-immunization, both the quadriceps and spleen were harvested. The quadriceps tissues were stored in PBS buffer, washed with saline, fixed in formalin, embedded in paraffin and cut into thick sections on slides $(4 \mu \mathrm{m})$. The slides were stained with hematoxylin and eosin (H\&E).

The spleens were temporarily pooled in a sterile lymphocyte culture medium to avoid cell death. The lymphocyte culture medium (LCM) contained $900 \mathrm{~mL}$ of RPMI 1640, $100 \mathrm{~mL}$ of FBS, $25 \mathrm{~mL}$ of HEPES (25 mM), and $50 \mu \mathrm{L}$ of $\beta$-mercaptoethanol (150 $\mu \mathrm{M})$. To obtain splenocyte samples, the spleen was gently pressed with the plunger seal of a 5-mL syringe on a $70-\mu \mathrm{m}$ cell strainer into a $50-\mathrm{mL}$ tube and washed through a cell strainer with RPMI 1640 containing $10 \%(v / v)$ FBS. Then, the washing buffer was removed by centrifugation at $1200 \mathrm{rpm}$ for $5 \mathrm{~min}$ at $4{ }^{\circ} \mathrm{C}$. The cell pellet was resuspended in $5 \mathrm{~mL}$ red blood cell lysis buffer (dilution from RBC lysis buffer $(10 \times)$, Biolegend, Lot: B166991) and incubated in an ice bath. Then, $30 \mathrm{~mL}$ of cold PBS was added for lysis quenching, and the supernatant was removed by centrifugation at $1200 \mathrm{rpm}$ for $5 \mathrm{~min}$ at $4{ }^{\circ} \mathrm{C}$. Finally, the cell pellets were 
gently resuspended in LCM. The cell solution was counted and diluted to the desired cell concentrations.

\subsubsection{Preparation of the Sera Samples}

C57BL/ 6 mice (six mice per group) were immunized on the same schedule as described in Section 2.5.1. Serum samples from immunized mice were collected by withdrawing submandibular blood at predetermined times, and they underwent a centrifugation at $7500 \mathrm{rpm}$ for $15 \mathrm{~min}$.

\subsection{MRNA Expression of T Cells}

A total of $5 \times 10^{6}$ cells $/ \mathrm{mL}$ splenocytes from immunized mice were seeded in 24-well plates and re-stimulated with or without OVA (low-endo; the final concentration of OVA was $10 \mu \mathrm{g} / \mathrm{mL}$ ). After $24 \mathrm{~h}$, the total RNA of splenocytes was extracted using TRIzol reagent (Invitrogen, Waltham, MA, USA) according to the manufacturer's instructions. An amount of $1 \mu \mathrm{g}$ of total RNA was used for cDNA synthesis with oligo (dT). Real-time PCR was carried out using the Light Cycler 480 II (Roche, Basel, Switzerland). The geometric mean of the housekeeping gene $\beta$-actin was used as an internal to normalize the variability in expression levels, and it was analyzed using the $2^{-\Delta \Delta C T}$ method.

\subsection{Cytotoxic T Lymphocyte-Mediated Killing Activity}

A total of $5 \times 10^{6}$ cells $/ \mathrm{mL}$ splenocytes from immunized mice were seeded in 24-well plates and re-stimulated with or without $1 \mu \mathrm{g} / \mathrm{mL} \mathrm{H}-2 \mathrm{~K}^{\mathrm{b}}$ OVA peptide $\left(\mathrm{OVA}_{257-264}\right.$, SIINFEKL, MBL, Code No.: TS-5001-P) for $24 \mathrm{~h}$ and detected by cell staining using antiCD8-PE (MBL, Code No.: D271-5), anti-CD19-PE-Cy7 (Biolegend, Cat No.: 115520) and Live/Dead-FITC. The stained OVA-specific CD8+ T cells (gating strategy: total cells/live cells/CD19-/CD8+) were analyzed by flow cytometry. The FACS data were analyzed and calculated by Flow Jo software (Version v10, Ashland, OR, USA), and the results are shown as the mean fluorescence intensity and population percentage.

\subsection{IgG and IgG Subtype Titers}

The titers of OVA-specific IgG and IgG subtypes were measured using goat antimouse IgG H\&L (HRP) (Abcam, Cambridge, UK), goat anti-mouse IgG1 (HRP) (Abcam, Cambridge, UK) and goat anti-mouse IgG2a (HRP) (Abcam, Cambridge, UK). OVA-specific IgG tracking was performed with the serial dilution method for analysis by ELISA; the titers were read as the UV absorbance signals, which twice exceeded the background value.

\subsection{Statistical Analysis}

The IgG antibodies are presented as geometric mean titers with $95 \%$ confidence intervals; the significance among the groups was determined by Tukey's one-way ANOVA tests to perform comparisons, followed by post hoc tests, and a $p$-value $<0.05$ was considered to indicate a statistically significant difference. The physicochemical characteristics and $\mathrm{T}$ cell responses are expressed as the mean \pm standard deviation (SD).

\section{Results and Discussion}

\subsection{Synthesis and Characterization of $\mathrm{HACH}$}

Cholesterol, a natural molecule that stabilizes cell membranes as well as liposome carriers, was used to confer an amphiphilic property to HA [35]; the cholesterol molecule represents the hydrophobic part of $\mathrm{HACH}$ conjugates and the synthetic procedures are shown in Figure 1. In the first step (i), the cholesterol was modified by Glycine-Boc using Steglish esterification to generate Boc-Gly cholesterol, and then (ii) the Boc group was removed by TFA/DCM. As shown in Figure S1, the characteristic peaks of cholesterol (methyl groups at 0.67, 0.86, 0.91, and $1.01 \mathrm{ppm}$ ) and tert-butyl group (Peak h, $1.45 \mathrm{ppm}$, singlet, $9 \mathrm{H}$ ) were observed in Boc-Gly cholesterol (Figure S1a) and the Boc peak at $1.45 \mathrm{ppm}$ disappeared after TFA incubation (Figure S1b), indicating a successful de-protection process 
for obtaining $\mathrm{NH}_{2}$-Gly-cholesterol. The molecular weight of $\mathrm{NH}_{2}$-Gly-cholesterol was also confirmed by mass spectroscopy.

(i)

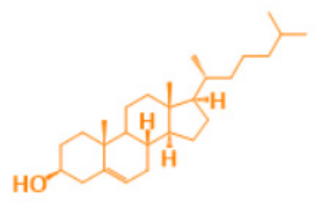

Cholesterol

(ii)

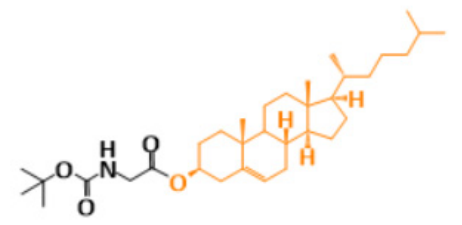

Boc-Gly-cholesterol

(iii)

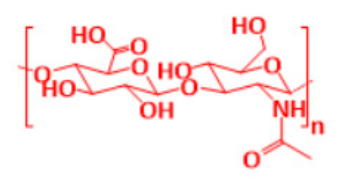

Hyaluronic acid

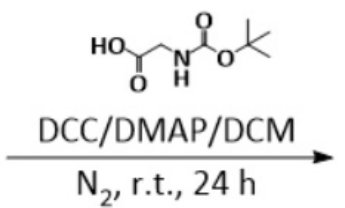

$\underset{\mathrm{N} \text {, r.t., } 3 \mathrm{~h}}{\stackrel{\mathrm{T}}{\mathrm{N}} \mathrm{PCM}}$

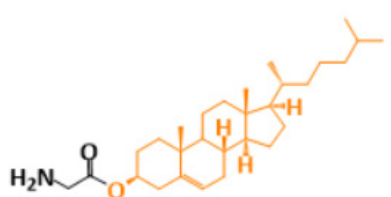

$\underset{\mathrm{DIC} / \mathrm{Oxyma}}{\stackrel{\text { r.t., } 24 \mathrm{~h}}{\longrightarrow}}$
Boc-Gly-cholesterol

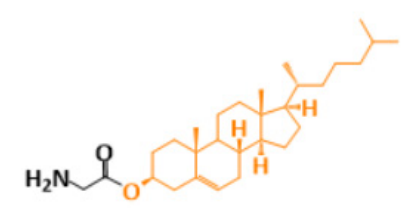

$\mathrm{NH}_{2}$-Gly-cholesterol

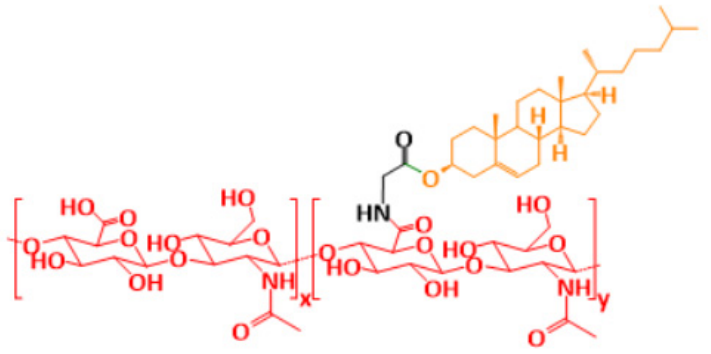

Hyaluronic acid-Gly-cholesterol

(HACH)

Figure 1. Synthetic pathway of HACH. In the first step, cholesterol was modified with Boc-Gly-OH by DCC/DMAP esterification. In the second step, the Boc group was removed under acidic conditions by TFA to produce $\mathrm{NH}_{2}-\mathrm{Gly}$ cholesterol. In the final step, $\mathrm{NH}_{2}$-Gly-cholesterol was conjugated to the carboxylic group of HA by DIC/Oxyma activation. (i) Modification of cholesterol; (ii) deprotection of Boc-Gly cholesterol; (iii) conjugation of Gly cholesterol on HA.

$\mathrm{HACH}$ with a glycine linker was synthesized using DIC/oxyma as an amide coupling agent to graft $\mathrm{NH}_{2}$-Gly-cholesterol onto $\mathrm{HA}$ in a DMSO $/ \mathrm{H}_{2} \mathrm{O}$ co-solvent system (iii). After dialysis and lyophilization, the cotton-like $\mathrm{HACH}$ product was obtained. It is noticed that the characteristic peaks of cholesterol (four peaks of methyl groups at 0.67, 0.86, 0.91 , and $1.01 \mathrm{ppm}$ ) in $\mathrm{HACH}$ were not observed in the ${ }^{1} \mathrm{H}-\mathrm{NMR}$ spectrum (Figure S1c), this finding suggested the presence of microphase-separated structure of HACH. Fieber et al. used self-diffusion NMR spectroscopy and relaxometry to explain this phenomenon of the hydrophobic core. They found that the rigidity of the hydrophobic core of the macromolecular structure would decrease the $\mathrm{T} 1$ and $\mathrm{T} 2$ relaxation times, which enabled the NMR signal to be undetectable [36]. In $\mathrm{HACH}$, it is speculated that the original hydrophilic HA chain exhibits high flexibility and mobility, and this property is influenced by cholesterol conjugation, resulting in an increase of mobility from the terminal side of cholesterol groups toward the HA backbone. Therefore, the signal peaks of cholesterol cannot be easily detected by ${ }^{1} \mathrm{H}-\mathrm{NMR}$ in $\mathrm{HACH}$.

The theoretical carbon to nitrogen $(\mathrm{C} / \mathrm{N})$ ratio of $\mathrm{HA}$ alone or $\mathrm{HACH}$ with $100 \%$ degree of substitution (DS) was 14 and 21.5, respectively. To determine the percentage of DS of cholesterol of $\mathrm{HACH}$, we employed EA to investigate the $\mathrm{C} / \mathrm{N}$ ratio of free $\mathrm{HA}$ and $\mathrm{HACH}$ and then calculated the DS ratio of HACH using Formula (1). As shown in Table 1, the actual $\mathrm{C} / \mathrm{N}$ of HA measured by EA was 14.0, this value was consistent with the theoretical $\mathrm{C} / \mathrm{N}$ ratio of $\mathrm{HA}$ and indicated the reliability of EA analysis in the determination 
of $\mathrm{C} / \mathrm{N}$ ratio of $\mathrm{HA}$ or HA-drug conjugates. The $\mathrm{C} / \mathrm{N}$ of HACH10 was 14.7 analyzed by EA and the DS ratio was calculated as $9.1 \%$ that was closed to the estimated DS ratio of $10 \%$. HACH20 revealed a C/N ratio of 15.0 , and DS ratio of $13.3 \%$ even though the DS ratio of $\mathrm{HACH}$ was estimated at $20 \%$ for the conjugation process. If the estimated DS ratio was increased to $30 \%$, the measured $\mathrm{C} / \mathrm{N}$ ratio was increased to 15.6 , and the DS ratio was $21.2 \%$; however, $\mathrm{HACH} 30$ would become insoluble in an aqueous solution and thus could not be utilized for further applications. Thus, $\mathrm{HACH} 20$ was utilized for further emulsion and biomedical investigations.

Table 1. $\mathrm{C} / \mathrm{N}$ ratio and $\mathrm{DS} \%$ of the cholesterol on $\mathrm{HA}$.

\begin{tabular}{|c|c|c|c|c|}
\hline & C Element (Mole\%) ${ }^{a}$ & N Element (Mole\%) ${ }^{a}$ & $\mathrm{C} / \mathrm{N}^{\mathbf{b}}$ & $\operatorname{DS}(\%)^{c}$ \\
\hline HA & 3.125 & 0.223 & 14.0 & - \\
\hline HACH10 & 3.314 & 0.226 & 14.7 & 9.2 \\
\hline $\mathrm{HACH} 20$ & 3.143 & 0.210 & 15.0 & 13.3 \\
\hline НАСН30 & 3.361 & 0.216 & 15.6 & 21.2 \\
\hline
\end{tabular}

\subsection{Self-Assembling Properties of HACH without or with Squalene}

As shown in Figure 2, the resulting HACH20 product (DS 13.3\%) is cloudy and well dispersed in an aqueous solution. In the TEM image, we found that $\mathrm{HACH}$ could selfassemble to form particles that were approximately $100 \mathrm{~nm}$, whereas the particle size of $\mathrm{HACH} 20$ analyzed by DLS was $301.5 \pm 3.2 \mathrm{~nm}$. This difference in size was suggested to be caused by hydrophilic swelling of hyaluronic acid on the surface of the HACH20 particles in aqueous conditions. It was also found that the HACH30 product with a higher DS ratio gave rise to an unsatisfactory water-dispersibility that might be due to the high hydrophobicity from the increased cholesterol content.

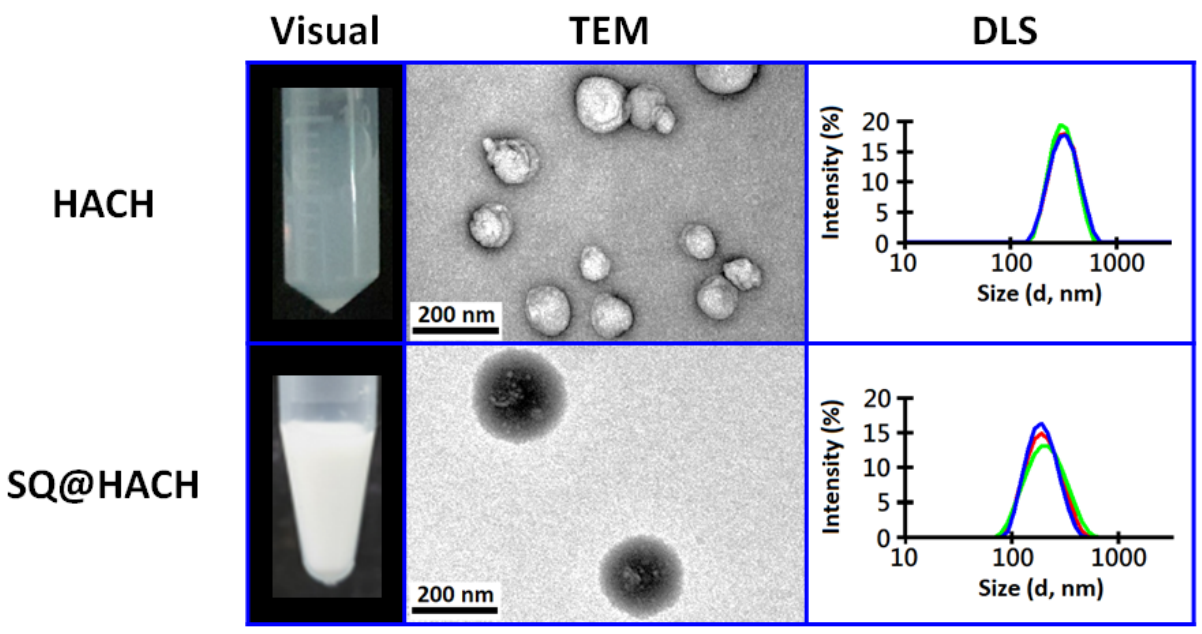

Figure 2. Visual appearance, TEM images and particle size distribution of HACH and SQ@HACH. The Size distribution was measured by DLS under 100-fold dilution of sample stock in water; colorful lines represent three different measurement results.

In order to evaluate the potential of amphiphilic $\mathrm{HACH}$ as an emulsifier for stabilizing the oil/water interfaces, $\mathrm{HACH} 20$ were mixed with $5 \%$ squalene and then passed through a high-pressure microfluidizer. As shown in Figure 2, an isotropic emulsified formulation (named SQ@HACH) was obtained after homogenization of the squalene/HACH20/citrate buffer. The TEM images reveal that SQ@HACH spherical particles were composed of some squalene droplets (bright core) surrounded by the amphiphilic $\mathrm{HACH}$ (dark shell). The results of DLS of SQ@HACH show a uniform size of around $190 \pm 2 \mathrm{~nm}$ and a 
polydispersity of $0.136 \pm 0.027$. Compared with the self-assembled HACH in aqueous solution, the smaller-sized SQ@HACH particles might be a result of the hydrophobic interactions between squalene and hydrophobic segment of $\mathrm{HACH}$ after passing through a microfluidizer. It is noticed that the emulsification process predominated the particle size of SQ@HACH (Figure S2) whereas free HA solutions with squalene immediately showed phase separation under the same process (Figure S3), indicating that HACH20 successfully stabilized the squalene/water interface. We also evaluated the emulsifying ability of low DS ratio of HACH10 and found that this was insufficient to form a stable squalene nanoemulsion in spite of its excellent water-dispersibility. Thus, squalene nanoemulsion using $13.3 \%$ DS ratio of $\mathrm{HACH} 20$ was employed for the following studies.

\subsection{Long-Term Storage of SQ@HACH}

SQ@HACH was stored in a refrigerator at $4{ }^{\circ} \mathrm{C}$ and an incubator at $37^{\circ} \mathrm{C}$ to mimic the stability of SQ@HACH in cold chain storage and human body conditions, respectively. The physical appearance, particle size, and polydispersity index of SQ@HACH were monitored for at least 20 weeks. As shown in Figure 3a, the physical appearance of SQ@HACH did not change significantly over 20 weeks when stored at $4{ }^{\circ} \mathrm{C}$.

(a) $4{ }^{\circ} \mathrm{C}$
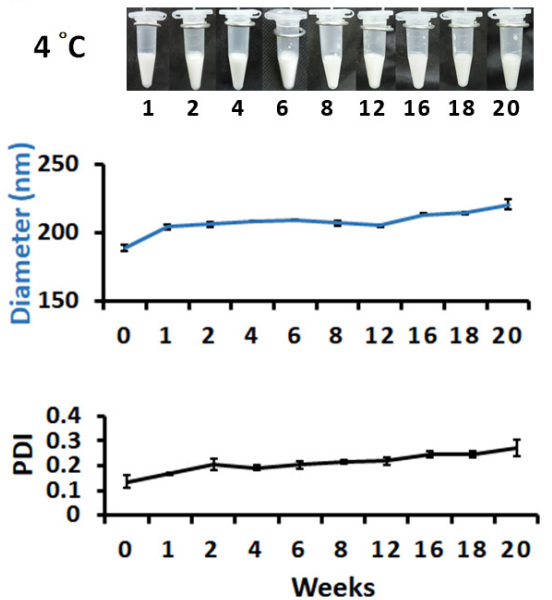

(b)
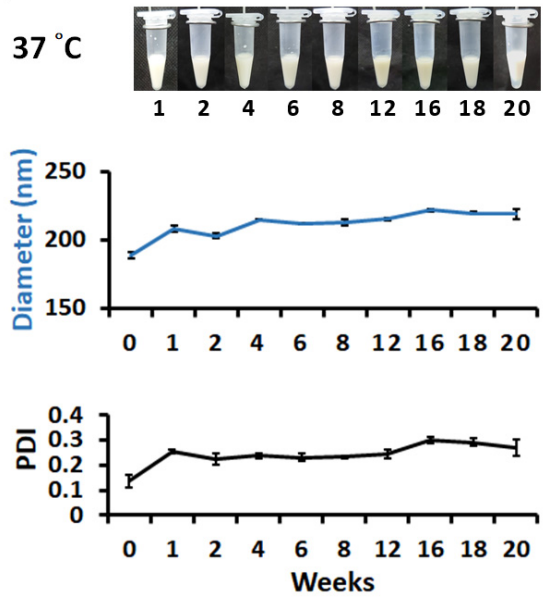

Figure 3. The changes of visual appearances, particle size and polydispersity index (PDI) of SQ@HACH upon storage at (a) $4{ }^{\circ} \mathrm{C}$ for 20 weeks and (b) $37^{\circ} \mathrm{C}$ for 20 weeks. The diameter and PDI of SQ@HACH (100-fold dilution) were measured by DLS. $(n=3$, mean \pm SD).

A significant increase in particle size of SQ@HACH from $190 \mathrm{~nm}$ to $200 \mathrm{~nm}$ was observed during the first 2 weeks, which might be due to coalescence induced by thermodynamic instability $[37,38]$. Then, SQ@HACH appeared to be stable in size from week 2 to week 16 . After 16 weeks, the particle size slightly increased due to instability, during which the PDI increased in a similar trend.

Upon storage at $37^{\circ} \mathrm{C}$, the physical appearance of SQ@HACH did not obviously change during the first 12 weeks, but it gradually changed from a milky white emulsion to a light-yellow emulsion after 12 weeks (Figure 3b). This gradual color change may be assumed to be caused by the accelerated oxidation of squalene at high temperatures [39]. A significant increase in particle size was detected from approximately $190 \mathrm{~nm}$ to $215 \mathrm{~nm}$ during the first 4 weeks. Next, the particle size was maintained in the range of $210-220 \mathrm{~nm}$ between week 4 and week 16 . After 16 weeks, the particle size remained at approximately $220 \mathrm{~nm}$; however, the PDI slightly increased during this period. At week 20, slight emulsion delamination occurred, and both the particle size and PDI increased.

These data reveal that SQ@HACH has good stability of $4{ }^{\circ} \mathrm{C}$ storage for at least 16 weeks, indicating the advantage of $\mathrm{SQ} @ \mathrm{HACH}$ for last-mile transportation. This feature may be considered as a favorable storage strategy that may not only reduce the cost of cold 
chain transportation but also expand the availability of medicines (drugs or vaccines) to areas devoid of cold chain facilities.

\subsection{Histological Examination of the Injection Site}

To assess the cell infiltration and absorbance of $\mathrm{HACH}$ and SQ@HACH at the injection site, C57BL/ 6 mice were divided into 4 groups including a control $(0.1 \mathrm{mM}$ sodium citrate buffer, $\mathrm{pH}=6.5$ ), OVA alone, OVA with SQ@HACH, and OVA with a conventional $\mathrm{AlPO}_{4}$ adjuvant; the latter was treated for comparison. Fourteen days after injection, the immunized mice were euthanized, and the muscle tissues of the injection site were removed for histological analysis. The H\&E-stained quadriceps muscle section is shown in Figure 4. There was no cell infiltration in the buffer control and OVA-alone groups (Figure 4a,b). The $\mathrm{AlPO}_{4}$ adjuvant was soluble in water, and the residue could not be observed in the examination; however, the infiltration of immune cells from the muscle tissue showed that OVA with the $\mathrm{AlPO}_{4}$ adjuvant induced a greater degree of local inflammation than SQ@HACH (Figure 4e). Similar to the OVA alone, we did not observe cell infiltration in the OVA with SQ@HACH group (Figure 4f). The SQ@HACH particles were almost absorbed, and the residue materials were clustered into several 10-20 $\mu \mathrm{m}$ vesicles, with a few recruited cells remaining. Overall, SQ@HACH shows tolerance following intramuscular injection in mice, a feature that can be further used in biomedical applications.

(a)

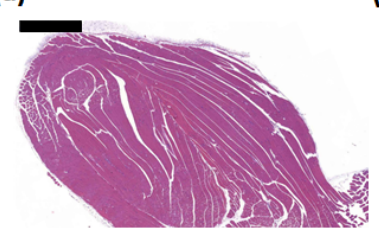

(b)

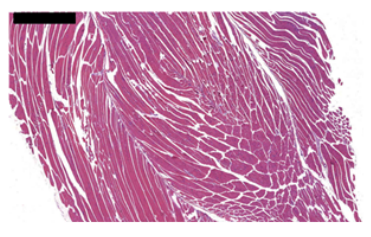

(c)

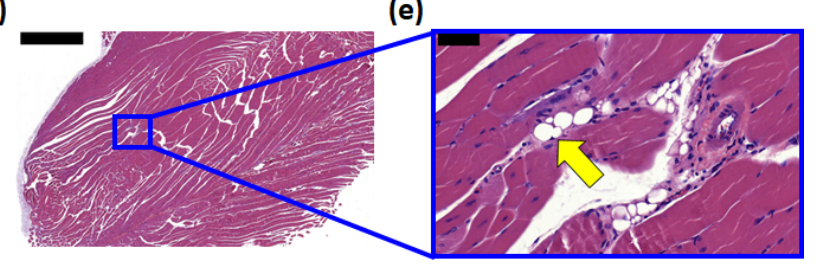

(d)

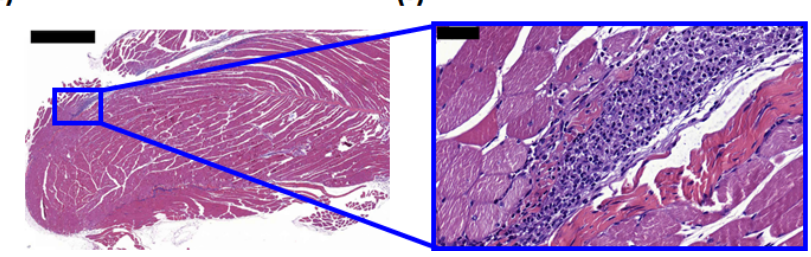

Figure 4. Histological analysis of the injection site in the quadriceps muscles. C57BL/6 mice were immunized with $100 \mu \mathrm{L}$ of (a) $10 \mathrm{mM}$ sodium citrate solution, $\mathrm{pH}=6.5$, (b) OVA $50 \mu \mathrm{g}$, (c,e) OVA $50 \mu \mathrm{g}$ with SQ@HACH, and (d,f) OVA $50 \mu \mathrm{g}$ with $\mathrm{AlPO}_{4}$ (aluminum content $30 \mu \mathrm{g}$ ) at quadriceps. The quadriceps muscle tissues were removed on day 14 and stained by H\&E staining. The muscle sections were observed by microscopy at magnification $(10 \times$ and $40 \times)$. Scale bar: $1000 \mu \mathrm{m}(\mathbf{a}-\mathbf{d})$ and $50 \mu \mathrm{m}(\mathbf{e}, \mathbf{f})$. The yellow arrow indicates the vesicles of SQ@HACH.

\subsection{Serum IgG Antibodies}

The production of OVA-specific IgG antibodies is one of the main evaluation criteria of vaccine efficacy for humoral immunity. To investigate the impact of SQ@HACH on B cell-mediated IgG secretion, blood was regularly collected from the immunized mice, and the serum was traced by an ELISA assay. As shown in Figure 5a, vaccination with OVA and SQ@HACH induced a geometric mean titer (GMT) of 8000 at week 2, and the highest GMT of 10,000 was titrated at week 4; beyond, this titer rapidly diminished after week 6 and showed the same GMT level as the OVA alone, but it should be noted that the humoral immunity was induced by a single injection. These results correlate with the results of histological analysis. SQ@HACH was quickly absorbed within a few weeks and did not cause long-term inflammation of the injection site. On the other hand, the $\mathrm{AlPO}_{4}$ group induced a GMT of 32,000 at week 4, and it maintained a GMT for more than 10,000 for at least 12 weeks. 
(a)

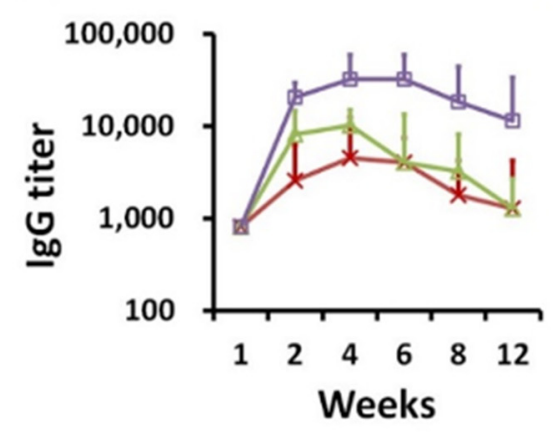

(b)

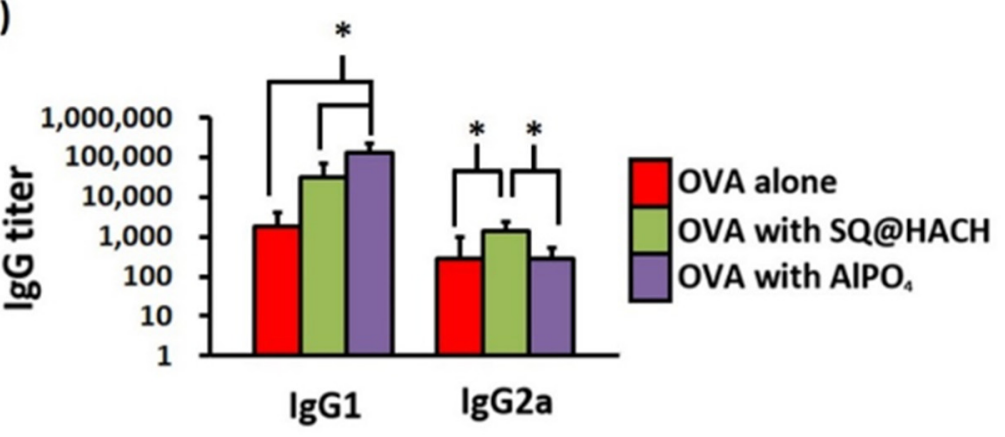

Figure 5. The impact of adjuvants on driving OVA-specific IgG antibodies in mice ( $n=6$ per group) treated with OVA alone, OVA with SQ@HACH and OVA with $\mathrm{AlPO}_{4}$ for 12 weeks. (a) IgG (b) IgG subtypes. The serum samples from immunized mice were collected for analysis by ELISA. The IgG subtypes were further analyzed in Week 4 by ELISA. The data are shown as the GMT $\pm 95 \%$ C.I. ${ }^{*} p<0.05$.

\subsection{Modulation of the Adjuvant-Mediated T Cell Activation}

To investigate the effects of SQ@HACH on the subsequent signal transduction of $\mathrm{T}$ cells, splenocytes from immunized mice were collected for primary culture without or with OVA stimulation. After $24 \mathrm{~h}$ of incubation, mRNA expression was detected by qPCR, and the housekeeping gene beta-actin was used as an internal control for normalization. The fold induction was calculated from the ratio of the expression levels with OVA re-stimulation to those without stimulation. The data show that immunization by OVA adjuvanted with SQ@HACH increased the mRNA expression of IFN- $\gamma$ (a Th1-type cytokine) and IL-4 (a Th2-type cytokine) compared with the OVA immunization without the formulation (Figure 6). These results are consistent with the mRNA expression of the specific key transcription factors T-bet (Th1) and GATA3 (Th2). We also detected the increased generation of IgG2a antibodies in the mice that received SQ@HACH-formulated OVA after 4 weeks of vaccination (Figure $5 b$ ), which predominated Th1 polarization. These findings suggest that SQ@HACH can enhance the related pathways of Th1 and Th2 cells simultaneously during the re-stimulation of OVA. It is important to note that the splenic cytokine secretion responses and serum IgG2a antibodies induced by OVA with $\mathrm{AlPO}_{4}$ adjuvant were the same as those induced by OVA alone, which is in agreement with the literature [40].

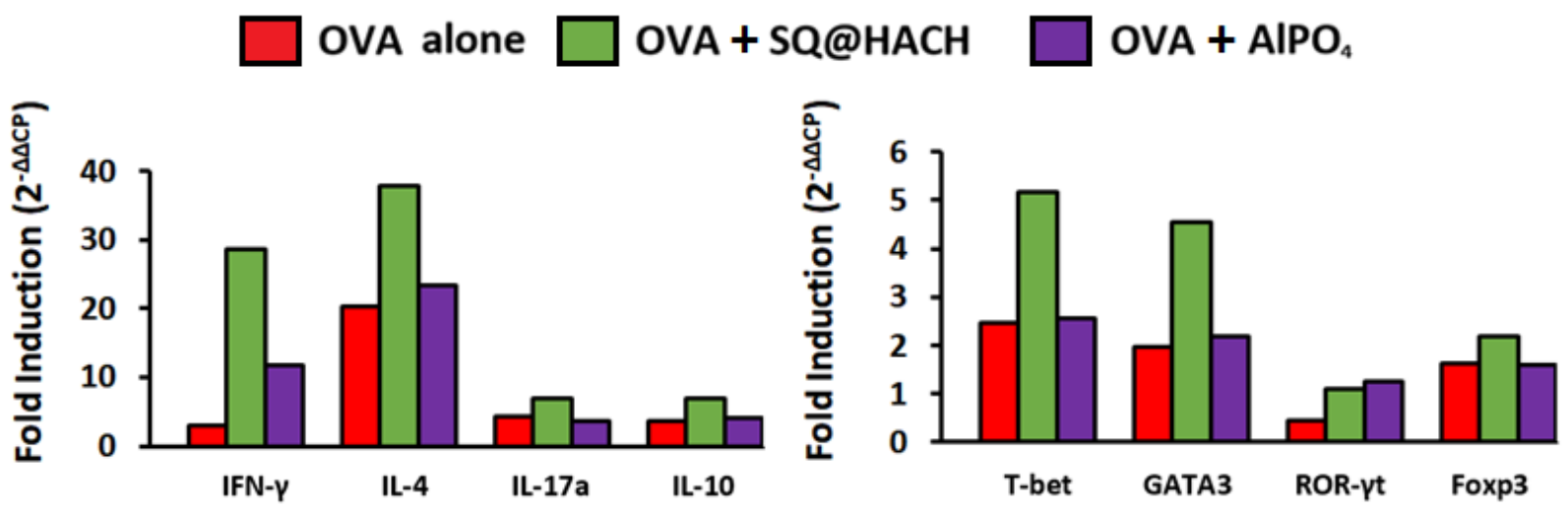

Figure 6. T cell-related mRNA quantification. Pooled splenocytes from immunized mice were obtained at day 14 after vaccination and re-stimulated with or without ovalbumin for $24 \mathrm{~h}$. The quantification of $\mathrm{T}$ cell-related mRNA expression by RT-PCR for IFN- $\gamma$, IL-4, IL-17a, IL-10, T-bet, GATA3, ROR- $\gamma$ t, and Foxp3. The fold induction is the ratio of the expression values with ovalbumin to those without ovalbumin. Results are expressed as the geometric mean of the housekeeping gene beta-actin which was used as an internal control to normalize the variability in expression levels. 
HA is known to play multifunctional roles in innate and adaptive immune responses via different receptors on immune cells [41]. HA-decoration can enhance cellular uptake efficiency by HA-CD44 receptor-mediated endocytosis in DCs [42,43], and it can also enhance the antigen delivery to lymph nodes which is likely to rely on the LYVE-1 receptors present on the endothelium of lymphatic vessels $[44,45]$. The above mechanisms facilitate the potential applications of HA or HA-derivatives as vaccine adjuvant candidates.

In addition, low molecular weight (LMW) HA fragments act as damage-associated molecular pattern molecules (DAMPs) [46,47], which are recognized by TLRs of a wide range of immune cells, especially TLR-4 triggered DC maturation [48,49], and TLR-2 engagement on DCs promotes effector and memory T helper (Th) cell response [47,50].

Thus, we speculate the generation of LMW HA fragments from the degradation of $\mathrm{HACH}$ can further activate DCs and enhance antigen recognition and antigen presentation to Th cells. Of note, Pietà et al. also report similar results on HA-bioconjugated OVA, and they indicate that HA also stimulates a T cell immunity, especially Th1 immune response, and leads to the generation of an OVA-specific cytotoxic response [51]. Detailed investigations are ongoing at our laboratory.

\subsection{Evaluation of the OVA-Specific Splenic Cytotoxic T Lymphocyte Response}

Cytotoxic T lymphocyte (CTL) immunity functions as the main defense against cancer and viral infections. In order to study whether SQ@HACH generated antigen-specific CTLs, splenocytes from immunized mice were collected and re-stimulated for $24 \mathrm{~h}$ with $\mathrm{H}-2 \mathrm{~K}^{\mathrm{b}}$ OVA peptide $\left(\mathrm{OVA}_{257-264}\right.$, SIINFEKL), a peptide sequence associated with the phagocytic activity of DCs that can bind to the $\mathrm{H}-2 \mathrm{~K}^{\mathrm{b}}$ of $\mathrm{MHC}$ class I [52]. As shown in Figure 7, there was no difference in CD8+ cells with $\mathrm{OVA}_{257-264}$ re-stimulation (MFI of $11,224)$ and those without stimulation (MFI of 11,160) in the OVA-alone group. Interestingly, for the mice that received SQ@HACH-adjuvanted OVA, the MFI increased to 25,000 under the stimulation of $\mathrm{OVA}_{257-264}$ peptide, which was higher than the detected level (MFI of 16,000) in the $\mathrm{AlPO}_{4}$ group. The higher MFI value from the SQ@HACH-adjuvanted group's splenocytes has a higher CD8 expression cell population than other groups when re-stimulated with $\mathrm{OVA}_{257-264}$ peptide. The upregulated CD8 expression can increase CTL activity against viral infections, a feature also found in COVID-19 patients recently [53]. In summary, the SQ@HACH-adjuvanted vaccine can enhance antigen-specific CTL immunity. An antigen-specific CTL response will be activated to attack when recognizable viral infections and cancer cells are encountered [54,55].

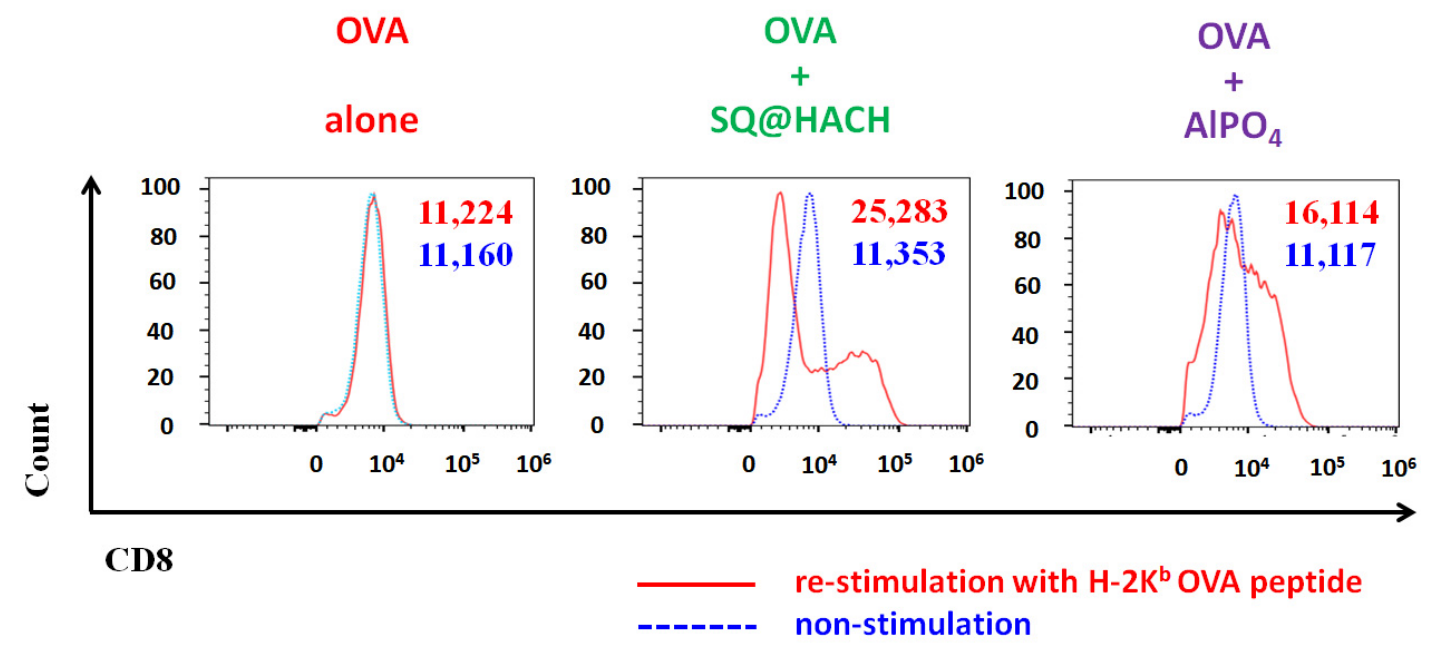

Figure 7. Activation of antigen-specific cytotoxic T lymphocytes. The splenocytes from immunized mice were obtained on day 14 after vaccination. Flow cytometric histograms and mean fluorescence intensity of CD8+ T cells were shown as re-stimulation for $24 \mathrm{~h}$ with $\mathrm{H}-2 \mathrm{~K}^{\mathrm{b}}$ OVA peptide $\left(\mathrm{OVA}_{257-264}\right.$, SIINFEKL) (red) or with medium only (blue), respectively. 
It has been reported that HA from the extracellular matrix is transiently broken down to LMW HA upon local inflammation during the early stage of infection [46], and LMW HA can directly activate TLRs [47]. Among these TLRs, TLR-2 plays the key role in enhancing effector and memory CD8 T cells response [56]. Thus, despite limited understanding of the role of SQ@HACH in CD8 T cell response, we speculated that the degradation of $\mathrm{HACH}$ could play a similar role as LMW HA to activate the proliferation of the effector CD8 T cells and further increase the probability of producing memory CD8 T cells. In the future, we will further explore the mechanisms in greater detail on how the SQ@HACH enhances CTL response.

Currently, nanotechnology is already applied to the design of vaccines. The importance of nanovaccines has been raised as a potent vaccine design to overcome the disadvantages of traditional vaccines $[34,57]$. These nanovaccine designs allow the encapsulation of antigen and adjuvant together to enhance immune stimulation, protect the antigens [58], and promote DCs maturation [59]. Furthermore, coating HA on the nanomaterial surface can also increase the permeability of the lymphatic vessels through lymphatic vessel endothelial receptor 1 (LYVE-1) [60], leading to the delivery of antigen to the lymph nodes. In this study, $\mathrm{HACH}$ was used a surfactant for the preparation of squalene nanoemulsion. The so-obtained SQ@HACH nanoemulsion can directly mix with antigen to evaluate the efficacy of SQ@HACH on immune stimulation. However, the function of antigen encapsulation has not yet been considered. Further investigations are warranted to tune the encapsulating parameters and manufacturing process on the design of HACH-based nanovaccines.

The above results indicate that the absorbance of SQ@HACH may reduce inflammation at the injection site. Nevertheless, SQ@HACH can accurately induce the immune activation of adjuvant-mediated OVA-specific splenic T cells in a single shot, especially the Th1-related CTL response. Moreover, SQ@HACH has great potential in vaccine storage and delivery due to its favorable stability. We will further investigate the relevant mechanisms between the SQ@HACH structural control and immune regulation in order to optimize the vaccine formulation and test its efficacy in the treatment of immune dysfunctions and infectious diseases.

\section{Conclusions}

In this study, we designed and synthesized a hyaluronic acid-glycine-cholesterol nanocomposite, $\mathrm{HACH}$, as an alternative emulsifier to the commonly used PEG-derivatives to avoid allergy risk. The amphiphilic structure enables $\mathrm{HACH}$ emulsification to stabilize the squalene/water interfaces, thus rendering uniform nanoemulsions (SQ@HACH) with an average diameter of approximately 190-220 nm. SQ@HACH showed good stability during storage and tolerance in vivo. As a vaccine adjuvant, SQ@HACH can enhance $\mathrm{T}$ cell cytokine-related mRNA expression and bias the trends of IgG subtype titers. Under stimulation with an OVA epitope peptide, splenocytes from mice that received SQ@HACHadjuvanted OVA had high CD8+ expression. Taken together, SQ@HACH has good potential as a candidate adjuvant for the development of vaccines against infectious diseases and cancer; moreover, the stability under mild storage condition is conducive to the distribution of vaccines.

Supplementary Materials: The following are available online at https:/ /www.mdpi.com/article/10 .3390 / pharmaceutics13101569/s1, Figure S1: Structural identification: ${ }^{1} \mathrm{H} N \mathrm{NR}\left(\mathrm{CDCl}_{3}, 400 \mathrm{MHz}\right)$ and mass spectrums (ESI-MS) of (a) Boc-Gly-cholesterol, (b) $\mathrm{NH}_{2}$-Gly-cholesterol; ${ }^{1} \mathrm{H}$ NMR spectrum $\left(\mathrm{D}_{2} \mathrm{O} / \mathrm{d} 6-\mathrm{DMSO}, 400 \mathrm{MHz}\right.$ ) of (c) HACH20, Figure S2: Size distribution of SQ@HACH with different passages: (a) 1 passage, (b) 2 passages, and (c) 3 passages through a microfluidizer, Figure S3: Appearance of (a) SQ@HA and (b) SQ@HACH. 5\% squalene was added to the solution containing $1 \% \mathrm{HA}$ and $1 \% \mathrm{HACH}$, homogenized and stood for $1 \mathrm{~h}$. 
Author Contributions: Conceptualization, C.-A.L., M.-H.H. and P.-S.L.; methodology, C.-A.L., H.-M.H. and P.V.; software, C.-A.L. and Y.-J.C.; formal analysis, C.-A.L.; investigation, C.-A.L., H.-M.H., Y.-J.C., C.-Y.H., T.-Y.C.; writing-original draft preparation, C.-A.L., Y.-H.L. and H.-Y.L.; writing-review and editing, M.-H.H. and P.-S.L.; supervision, M.-H.H. and P.-S.L.; project administration, M.-H.H. and P.-S.L.; funding acquisition, M.-H.H. and P.-S.L. All authors have read and agreed to the published version of the manuscript.

Funding: This research was funded by the Ministry of Science and Technology of Taiwan (MOST 1092113-M-005-020, 110-2124-M-005-001-MY3 to P.-S.L.), (MOST 109-2314-B-400-018-MY3 to H.-M.H.), the Ministry of Education (109RA112 to P.-S.L.) and the National Health Research Institutes (NHRI) of Taiwan (110A1-IVPP18-014).

Institutional Review Board Statement: The animal study was conducted according to the guidelines of the Animal Center of National Health Research Institutes (NHRI) and approved by the animal committee of the NHRI (NHRI-IACUC-107149).

Informed Consent Statement: Not applicable.

Data Availability Statement: The data presented in this study are available on request from the corresponding author.

Acknowledgments: The authors gratefully acknowledge the support of Chung-Hsiung Huang for suggesting the histological analysis and the Instrument Center of National Chung Hsing University for help with measurements of the transmission electron microscope (EM0000019200) and elemental analyzer (EA000100).

Conflicts of Interest: The authors declare no conflict of interest. Yu-Hsing Lin and Hua-Yang Lin are from Holy Stone Healthcare Co., Ltd. The company and funders had no role in the design of the study; in the collection, analyses, or interpretation of data; in the writing of the manuscript, and in the decision to publish the results.

\section{References}

1. Mascola, J.R.; Fauci, A.S. Novel vaccine technologies for the 21st century. Nat. Rev. Immunol. 2020, 20, 87-88. [CrossRef] [PubMed]

2. Jeyanathan, M.; Afkhami, S.; Smaill, F.; Miller, M.S.; Lichty, B.D.; Xing, Z. Immunological considerations for COVID-19 vaccine strategies. Nat. Rev. Immunol. 2020, 20, 615-632. [CrossRef] [PubMed]

3. Pulendran, B.; Arunachalam, P.S.; O'Hagan, D.T. Emerging concepts in the science of vaccine adjuvants. Nat. Rev. Drug Discov. 2021, 20, 454-475. [CrossRef] [PubMed]

4. Del Giudice, G.; Rappuoli, R.; Didierlaurent, A.M. Correlates of adjuvanticity: A review on adjuvants in licensed vaccines. Semin. Immunol. 2018, 39, 14-21. [CrossRef]

5. Krishnan, L.; Dicaire, C.J.; Patel, G.B.; Sprott, G.D. Archaeosome vaccine adjuvants induce strong humoral, cell-mediated, and memory responses: Comparison to conventional liposomes and alum. Infect. Immun. 2000, 68, 54-63. [CrossRef]

6. Tandrup Schmidt, S.; Foged, C.; Smith Korsholm, K.; Rades, T.; Christensen, D. Liposome-based adjuvants for subunit vaccines: Formulation strategies for subunit antigens and immunostimulators. Pharmaceutics 2016, 8, 7. [CrossRef]

7. Petrovsky, N. Comparative safety of vaccine adjuvants: A summary of current evidence and future needs. Drug Saf. 2015, 38, 1059-1074. [CrossRef]

8. Su, J.R.; Moro, P.L.; Ng, C.S.; Lewis, P.W.; Said, M.A.; Cano, M.V. Anaphylaxis after vaccination reported to the Vaccine Adverse Event Reporting System, 1990-2016. J. Allergy Clin. Immunol. 2019, 143, 1465-1473. [CrossRef]

9. Sellaturay, P.; Nasser, S.; Ewan, P. Polyethylene glycol-induced systemic allergic reactions (anaphylaxis). J. Allergy Clin. Imunol. Pract. 2021, 9, 670-675. [CrossRef]

10. Badiu, I.; Geuna, M.; Heffler, E.; Rolla, G. Hypersensitivity reaction to human papillomavirus vaccine due to polysorbate 80 . Case Rep. 2012, 2012, bcr0220125797-b. [CrossRef]

11. Garvey, L.H.; Nasser, S. Anaphylaxis to the first COVID-19 vaccine: Is polyethylene glycol (PEG) the culprit? Br. J. Anaesth. 2021, 126, e106-e108. [CrossRef]

12. Ho, N.I.; Raaijmakers, T.K.; Adema, G.J. Adjuvants enhancing cross-presentation by dendritic cells: The key to more effective vaccines? Front. Immunol. 2018, 9, 2874. [CrossRef] [PubMed]

13. Verbeke, R.; Lentacker, I.; De Smedt, S.C.; Dewitte, H. The dawn of mRNA vaccines: The COVID-19 case. J. Control. Release 2021, 333, 511-520. [CrossRef] [PubMed]

14. Castells, M.C.; Phillips, E.J. Maintaining safety with SARS-CoV-2 vaccines. N. Engl. J. Med. 2021, 384, 643-649. [CrossRef]

15. Stone, C.A.; Liu, Y.; Relling, M.V.; Krantz, M.S.; Pratt, A.L.; Abreo, A.; Hemler, J.A.; Phillips, E.J. Immediate hypersensitivity to polyethylene glycols and polysorbates: More common than we have recognized. J. Allergy Clin. Imunol. Pract. 2019, 7, 1533-1540. [CrossRef] [PubMed] 
16. Povsic, T.J.; Lawrence, M.G.; Lincoff, A.M.; Mehran, R.; Rusconi, C.P.; Zelenkofske, S.L.; Huang, Z.; Sailstad, J.; Armstrong, P.W.; Steg, P.G. Pre-existing anti-PEG antibodies are associated with severe immediate allergic reactions to pegnivacogin, a PEGylated aptamer. J. Allergy Clin. Immunol. 2016, 138, 1712-1715. [CrossRef] [PubMed]

17. Kim, K.; Choi, H.; Choi, E.S.; Park, M.-H.; Ryu, J.-H. Hyaluronic acid-coated nanomedicine for targeted cancer therapy. Pharmaceutics 2019, 11, 301. [CrossRef] [PubMed]

18. Schanté, C.E.; Zuber, G.; Herlin, C.; Vandamme, T.F. Chemical modifications of hyaluronic acid for the synthesis of derivatives for a broad range of biomedical applications. Carbohydr. Polym. 2011, 85, 469-489. [CrossRef]

19. Bowman, S.; Awad, M.E.; Hamrick, M.W.; Hunter, M.; Fulzele, S. Recent advances in hyaluronic acid based therapy for osteoarthritis. Clin. Transl. Med. 2018, 7, 6. [CrossRef]

20. Shin, Y.S.; Kwon, W.J.; Cho, E.B.; Park, E.J.; Kim, K.H.; Kim, K.J. A case of cellulitis-like foreign body reaction after hyaluronic acid dermal filler injection. Dermatol. Sin. 2018, 36, 46-49. [CrossRef]

21. Kim, J.H.; Choi, J.S.; Yun, J.H.; Kang, H.K.; Baek, J.O.; Roh, J.Y.; Lee, J.R. Foreign body reaction to injectable hyaluronic acid: Late granuloma formation. Ann. Dermatol. 2015, 27, 224-225. [CrossRef] [PubMed]

22. Beleznay, K.; Carruthers, J.D.; Carruthers, A.; Mummert, M.E.; Humphrey, S. Delayed-onset nodules secondary to a smooth cohesive $20 \mathrm{mg} / \mathrm{mL}$ hyaluronic acid filler: Cause and management. Dermatol. Surg. 2015, 41, 929-939. [CrossRef] [PubMed]

23. Richter, A.; Ryde, E.; Zetterström, E. Non-immunogenicity of a purified sodium hyaluronate preparation in man. Int. Arch. Allergy Immunol. 1979, 59, 45-48. [CrossRef] [PubMed]

24. Hamilton, R.G.; Strobos, J.; Adkinson, N.F., Jr. Immunogenicity studies of cosmetically administered nonanimal-stabilized hyaluronic acid particles. Dermatol. Surg. 2007, 33, S176-S185.

25. Necas, J.; Bartosikova, L.; Brauner, P.; Kolar, J. Hyaluronic acid (hyaluronan): A review. Vet. Med. 2008, 53, 397-411. [CrossRef]

26. Slevin, M.; Krupinski, J.; Gaffney, J.; Matou, S.; West, D.; Delisser, H.; Savani, R.C.; Kumar, S. Hyaluronan-mediated angiogenesis in vascular disease: Uncovering RHAMM and CD44 receptor signaling pathways. Matrix Biol. 2007, 26, 58-68. [CrossRef]

27. Sheehan, K.M.; DeLott, L.B.; West, R.A.; Bonnema, J.D.; DeHeer, D.H. Hyaluronic acid of high molecular weight inhibits proliferation and induces cell death in U937 macrophage cells. Life Sci. 2004, 75, 3087-3102. [CrossRef] [PubMed]

28. Bodo, M.; Pezzetti, F.; Baroni, T.; Carinci, F.; Arena, N.; Nicoletti, I.; Becchetti, E. Hyaluronic acid modulates growth, morphology and cytoskeleton in embryonic chick skin fibroblasts. Int. J. Dev. Biol. 2002, 37, 349-352.

29. Harvima, I.T.; Heikura, H.; Hyttinen, M.; Naukkarinen, A. Hyaluronic acid inhibits the adherence and growth of monolayer keratinocytes but does not affect the growth of keratinocyte epithelium. Arch. Dermatol. Res. 2006, 298, 207-219. [CrossRef]

30. Rayahin, J.E.; Buhrman, J.S.; Zhang, Y.; Koh, T.J.; Gemeinhart, R.A. High and low molecular weight hyaluronic acid differentially influence macrophage activation. ACS Biomater. Sci. Eng. 2015, 1, 481-493. [CrossRef]

31. Tolg, C.; Hamilton, S.R.; Nakrieko, K.-A.; Kooshesh, F.; Walton, P.; McCarthy, J.B.; Bissell, M.J.; Turley, E.A. Rhamm ${ }^{-/-}$fibroblasts are defective in CD44-mediated ERK1, 2 motogenic signaling, leading to defective skin wound repair. J. Cell Biol. 2006, 175, 1017-1028. [CrossRef] [PubMed]

32. Do, Y.; Nagarkatti, P.S.; Nagarkatti, M. Role of CD44 and hyaluronic acid (HA) in activation of alloreactive and antigen-specific T cells by bone marrow-derived dendritic cells. J. Immunother. 2004, 27, 1-12. [CrossRef] [PubMed]

33. Moon, S.-h.; Shin, E.-C.; Noh, Y.-W.; Lim, Y.T. Evaluation of hyaluronic acid-based combination adjuvant containing monophosphoryl lipid A and aluminum salt for hepatitis B vaccine. Vaccine 2015, 33, 4762-4769. [CrossRef] [PubMed]

34. Liu, L.; Cao, F.; Liu, X.; Wang, H.; Zhang, C.; Sun, H.; Wang, C.; Leng, X.; Song, C.; Kong, D.; et al. Hyaluronic acid-modified cationic Lipid-PLGA hybrid nanoparticles as a nanovaccine induce robust humoral and cellular immune responses. ACS Appl. Mater. Interfaces 2016, 8, 11969-11979. [CrossRef]

35. Briuglia, M.-L.; Rotella, C.; McFarlane, A.; Lamprou, D.A. Influence of cholesterol on liposome stability and on in vitro drug release. Drug Deliv. Transl. Res. 2015, 5, 231-242. [CrossRef] [PubMed]

36. Fieber, W.; Herrmann, A.; Ouali, L.; Velazco, M.I.; Kreutzer, G.; Klok, H.-A.; Ternat, C.; Plummer, C.J.; Månson, J.-A.E.; Sommer, H. NMR diffusion and relaxation studies of the encapsulation of fragrances by amphiphilic multiarm star block copolymers. Macromolecules 2007, 40, 5372-5378. [CrossRef]

37. Huang, C.-Y.; Huang, M.-H. Emulsifying properties and degradation characteristics of bioresorbable polymeric emulsifiers in aqueous solution and oil-in-water emulsion. Polym. Degrad. Stab. 2017, 139, 138-142. [CrossRef]

38. Capek, I. Degradation of kinetically-stable o/w emulsions. Adv. Colloid Interfaces Sci. 2004, 107, 125-155. [CrossRef]

39. Saint-Leger, D.; Bague, A.; Lefebvre, E.; Cohen, E.; Chivot, M. A possible role for squalene in the pathogenesis of acne. II. In vivo study of squalene oxides in skin surface and intra-comedonal lipids of acne patients. Br. J. Dermatol. 1986, 114, 543-552. [CrossRef]

40. Yanase, N.; Toyota, H.; Hata, K.; Yagyu, S.; Seki, T.; Harada, M.; Kato, Y.; Mizuguchi, J. OVA-bound nanoparticles induce OVA-specific IgG1, IgG2a, and IgG2b responses with low IgE synthesis. Vaccine 2014, 32, 5918-5924. [CrossRef]

41. Lee-Sayer, S.S.; Dong, Y.; Arif, A.A.; Olsson, M.; Brown, K.L.; Johnson, P. The where, when, how, and why of hyaluronan binding by immune cells. Front. Immunol. 2015, 6, 150. [CrossRef]

42. Cao, F.; Yan, M.; Liu, Y.; Liu, L.; Ma, G. Photothermally controlled MHC class I restricted CD8+ T-cell responses elicited by hyaluronic acid decorated gold nanoparticles as a vaccine for cancer immunotherapy. Adv. Healthc. Mater. 2018, 7, 1701439. [CrossRef]

43. Nawwab Al-Deen, F.M.; Selomulya, C.; Kong, Y.Y.; Xiang, S.D.; Ma, C.; Coppel, R.L.; Plebanski, M. Design of magnetic polyplexes taken up efficiently by dendritic cell for enhanced DNA vaccine delivery. Gene Ther. 2014, 21, 212-218. [CrossRef] 
44. Johnson, L.A.; Banerji, S.; Lawrance, W.; Gileadi, U.; Prota, G.; Holder, K.A.; Roshorm, Y.M.; Hanke, T.; Cerundolo, V.; Gale, N.W.; et al. Dendritic cells enter lymph vessels by hyaluronan-mediated docking to the endothelial receptor LYVE-1. Nat. Immunol. 2017, 18, 762-770. [CrossRef]

45. Yoo, E.; Salyer, A.C.; Brush, M.J.; Li, Y.; Trautman, K.L.; Shukla, N.M.; De Beuckelaer, A.; Lienenklaus, S.; Deswarte, K.; Lambrecht, B.N. Hyaluronic acid conjugates of TLR7/8 agonists for targeted delivery to secondary lymphoid tissue. Bioconj. Chem. 2018, 29, 2741-2754. [CrossRef]

46. Ruppert, S.; Hawn, T.; Arrigoni, A.; Wight, T.; Bollyky, P. Tissue integrity signals communicated by high-molecular weight hyaluronan and the resolution of inflammation. Immunol. Res. 2014, 58, 186-192. [CrossRef]

47. Scheibner, K.A.; Lutz, M.A.; Boodoo, S.; Fenton, M.J.; Powell, J.D.; Horton, M.R. Hyaluronan fragments act as an endogenous danger signal by engaging TLR2. J. Immunol. 2006, 177, 1272-1281. [CrossRef] [PubMed]

48. Termeer, C.; Benedix, F.; Sleeman, J.; Fieber, C.; Voith, U.; Ahrens, T.; Miyake, K.; Freudenberg, M.; Galanos, C.; Simon, J.C. Oligosaccharides of Hyaluronan activate dendritic cells via toll-like receptor 4. J. Exp. Med. 2002, 195, 99-111. [CrossRef] [PubMed]

49. Fang, H.; Ang, B.; Xu, X.; Huang, X.; Wu, Y.; Sun, Y.; Wang, W.; Li, N.; Cao, X.; Wan, T. TLR4 is essential for dendritic cell activation and anti-tumor T-cell response enhancement by DAMPs released from chemically stressed cancer cells. Cell. Mol. Immunol. 2014, 11, 150-159. [CrossRef] [PubMed]

50. Chandran, S.S.; Verhoeven, D.; Teijaro, J.R.; Fenton, M.J.; Farber, D.L. TLR2 engagement on dendritic cells promotes high frequency effector and memory CD4 T cell responses. J. Immunol. 2009, 183, 7832-7841. [CrossRef]

51. Dalla Pietà, A.; Carpanese, D.; Grigoletto, A.; Tosi, A.; Dalla Santa, S.; Pedersen, G.K.; Christensen, D.; Meléndez-Alafort, L.; Barbieri, V.; De Benedictis, P. Hyaluronan is a natural and effective immunological adjuvant for protein-based vaccines. Cell. Mol. Immunol. 2021, 18, 1197-1210. [CrossRef]

52. Falo, L.D.; Kovacsovics-Bankowski, M.; Thompson, K.; Rock, K.L. Targeting antigen into the phagocytic pathway in vivo induces protective tumour immunity. Nat. Med. 1995, 1, 649-653. [CrossRef]

53. Ganji, A.; Farahani, I.; Khansarinejad, B.; Ghazavi, A.; Mosayebi, G. Increased expression of CD8 marker on T-cells in COVID-19 patients. Blood Cells Mol. Dis. 2020, 83, 102437. [CrossRef]

54. Menares, E.; Gálvez-Cancino, F.; Cáceres-Morgado, P.; Ghorani, E.; López, E.; Díaz, X.; Saavedra-Almarza, J.; Figueroa, D.A.; Roa, E.; Quezada, S.A.; et al. Tissue-resident memory CD8+ T cells amplify anti-tumor immunity by triggering antigen spreading through dendritic cells. Nat. Commun. 2019, 10, 4401. [CrossRef]

55. Woodland, D.L.; Kohlmeier, J.E. Migration, maintenance and recall of memory T cells in peripheral tissues. Nat. Rev. Immunol. 2009, 9, 153-161. [CrossRef]

56. Mercier, B.C.; Cottalorda, A.; Coupet, C.-A.; Marvel, J.; Bonnefoy-Bérard, N. TLR2 engagement on CD8 T cells enables generation of functional memory cells in response to a suboptimal TCR signal. J. Immunol. 2009, 182, 1860-1867. [CrossRef]

57. Diaz-Arévalo, D.; Zeng, M. Nanoparticle-based vaccines: Opportunities and limitations. In Nanopharmaceuticals; Elsevier: Amsterdam, The Netherlands, 2020; pp. 135-150.

58. Liu, L.; Kshirsagar, P.; Christiansen, J.; Gautam, S.K.; Aithal, A.; Gulati, M.; Kumar, S.; Solheim, J.C.; Batra, S.K.; Jain, M. Polyanhydride nanoparticles stabilize pancreatic cancer antigen MUC4ß. J. Biomed. Mater. Res. Part A 2021, 109, 893-902. [CrossRef] [PubMed]

59. Banerjee, K.; Gautam, S.K.; Kshirsagar, P.; Ross, K.A.; Spagnol, G.; Sorgen, P.; Wannemuehler, M.J.; Narasimhan, B.; Solheim, J.C.; Kumar, S. Amphiphilic polyanhydride-based recombinant MUC4 $\beta$-nanovaccine activates dendritic cells. Genes Cancer 2019, 10, 52. [CrossRef] [PubMed]

60. Bhang, S.H.; Won, N.; Lee, T.-J.; Jin, H.; Nam, J.; Park, J.; Chung, H.; Park, H.-S.; Sung, Y.-E.; Hahn, S.K. Hyaluronic acid-quantum dot conjugates for in vivo lymphatic vessel imaging. ACS Nano 2009, 3, 1389-1398. [CrossRef] [PubMed] 